\title{
Terrorism, Disasters, and Security
}

\author{
David Alexander, PhD
}

\author{
Scientific Director \\ Region of Lombardy School of Civil \\ Protection, Milan, Italy \\ Correspondence: \\ Professor David Alexander, $\mathrm{PhD}$ \\ Borgo Sarchiani 19 \\ 50026 San Casciano in Val di Pesa (FI), \\ Italy \\ E-mail: catastrophe@tiscali.it \\ or \\ 94 The Dormers \\ Highworth, Wiltshire SN6 7PD \\ United Kingdom \\ E-mail: the.catastrophe@virgin.net
}

Keywords: civil contingencies; classification of disasters; disaster planning; emergency scenarios; homeland security; risk analysis; security; terrorism

\section{Abbreviations: \\ UK = United Kingdom \\ US $=$ United States of America}

Web publication: 15 March 2004

\begin{abstract}
The purpose of this editorial is to explore the relationship between the new global emphasis on terrorism and the developing academic and practical fields of disaster management. It includes an appraisal of the place of terrorism among the various forms of disaster, a consideration of its relationship to risk assessment and its place in the practical handling of risks and incidents, and some reflections on the role of the private sector in security management. The influence on the current attitude toward managing the terrorism threat by the evolution of the disaster management field is considered and some of the problems with defining scenarios for counter-terrorism planning also are discussed.
\end{abstract}

Alexander D: Terrorism, Disasters, and Security. Prehosp Disast Med 2003;18(3):165-169.

\section{Introduction}

The purpose of this editorial is to serious the terrorist threat may be, explore the relationship between the excessive emphasis on managing only new global emphasis on terrorism this aspect of disaster management and the developing academic and can lead to diseconomies of scale in practical fields of disaster manage- terms of the neglect of other hazards, ment. I begin with an appraisal of and to retrograde measures more the place of terrorism among the var- characteristic of earlier phases in the ious forms of disaster. I then consid- evolution of civil defense.

er its relationship to risk assessment and its place in the practical han- Defining Disaster in Light of a dling of risks and incidents. In this, I New Emphasis on Terrorism include some reflections on the role One senses that the disarray that has of the private sector in security man- long afflicted the theorists of disaster agement. Next, I consider how the has been increased by the renewed evolution of the disaster manage- attention being given to the challenge ment field has influenced the current of combating terrorism. Disaster is, in attitude to managing the terrorism any case, a multi-farious concept that threat. Finally, in light of these seems to defy a precise definition., ${ }^{1,2}$ developments, I discuss some of the Perhaps, this hardly is surprising when problems with defining scenarios for one considers that at least 35 different counter-terrorism planning. disciplines and professions are

Terrorism and other forms of involved in studying, managing, and disaster overlap one another quite reducing the risks of calamity. The substantially both as destructive intellectual development of the field phenomena and as management has taken place in parallel under the problems. But, however large and aegis of seven different schools of 
thought, broadly allied to the subject areas of geography and anthropology (as human ecology), sociology, psychology, the geophysical and construction sciences, the medical sciences, development studies, and economics (now that terrorism is back on the agenda, we might add criminal justice as an eighth field). It is paradoxical that there is a prevailing intellectual climate of fragmentation at the same time as there is substantial overlap between the classes of natural, technological, and social phenomena that form the taxonomy of disaster. ${ }^{3}$ This is a complex field, and it is bound to react in complex ways to the renewed interest in terrorism.

Over the years, natural disaster has ceased to be interpreted as the manifestation of imponderable, unmanageable "Acts of God", and has come to be viewed in terms of failure to prepare for and protect against damaging events. ${ }^{4}$ Thus, "natural disaster" has acquired greater meaning in terms of human failings than it had when fate was considered to be the prime mover: the "natural" is now merely a convenience term. Here begins a process of convergence with terrorism. The latter-defined as the calculated use of intimidation, coercion, direct violent action or the engenderment of fear to attain goals that are political, religious, or ideological in nature ${ }^{5}$-is the end member of a spectrum that encompasses a range of ills from "man's inhumanity to man" to negligence in planning, and to the vulnerability of settlements, organizations, and people.

As an illustration of the connection, in the El Salvador earthquake of 17 January 2001 and the Bam Iran earthquake of 26 December 2003, hospitals, the most vital life-saving institutions of all, collapsed because they were poorly constructed, despite the presence of a familiar, well-demonstrated seismic risk and the technical know-how to make them resistant to the shaking. ${ }^{6}$ This, too, implies culpability and moral laxity just as, to most of us, terrorism does.

These reflections beg the question to what extent is terrorism a phenomenon that stands apart from other forms of disaster? Perhaps, we can distinguish four sources of calamity: (1) natural hazards such as tornadoes and earthquakes; (2) technological hazards such as toxic spills and transportation crashes; (3) social hazards such as riots and crowd crushes; and (4) the teleological hazard of terrorist outrages (so called because human malevolence is involved). The classification is not an absolute one, as there is considerable overlap between one class and another; for example, in the relevance of explosions to both technological and teleological events, or the fine dividing line between disruptive social action and outright terrorism. Moreover, certain phenomena, such as epidemics and epizootics, sit rather poorly with the categories. However, whether in its own category or in others, terrorism can be placed in the taxonomy of disasters.

\section{Terrorism and Risk Apportionment}

In the modern resurgence of terrorism is part of a complex pattern of global changes and imbalances. ${ }^{7}$ Over the years, the highly developed nations have become accustomed to the gradual decline of risk and increase in safety. Yet, at the same time, new forms and magnitudes of risk-taking have arisen to take the place of those risks (cholera, for example) that have been brought under control. However, there is a growing perception that life is becoming riskier in the Western world. ${ }^{8}$ In part, this is because, rather than being conquered, risk has been redistributed from the rich nations to the world's two billion poor people. One might regard some of the forms of terrorism and social instability as attempts to re-export it to its original source. Whether or not this is true, there is a palpable sense of anxiety in the West leading to the rise of forms of risk intolerance in which the concept of safety is taken to exaggerated levels. It has little to do with the actual levels of risk, though it should be kept in mind that, however well-known these are for disasters in general, they are virtually impossible to calculate for terrorist outrages. ${ }^{9}$

In 1995, Horlick-Jones presented a theory of disaster as a perceived betrayal of trust by the authorities who are supposed to guarantee safety. ${ }^{10}$ The model is, in some respects, peculiarly British, in that the United Kingdom (UK) culture includes a strong element of deference to experts, but it fits nicely with a more general tendency to opt for risk aversion, the reduction of risks at any cost. In terms of rational risk balancing, this leads to considerable distortion in investment levels between one form of risk and another. ${ }^{11}$

The problem with risk is that it remains a hypothetical quantity until it manifests itself as an event. This fact does not particularly trouble the engineer who has to calculate the probability that load stresses will be exceeded in a bridge or building; but it is a different matter for anti-terrorism strategists. Hence, the terrorism problem is akin to the "millennium bug" story: nobody knows whether timely intervention by information technologists in 1999 saved the world from chaos brought on by failed computer systems or whether the whole thing was a ridiculous overreaction. In terrorism, moreover, the precautionary principle only can be applied to a limited extent; otherwise the preparedness costs will spiral completely out of control.

\section{Practical Approaches}

If risk management is difficult, at least better emergency management is likely to help society cope with terrorism efficiently when it happens. The academic study and practical exercise of disaster-management capability make up a "transverse" subject, whose identity depends on the connections between its constituent disciplines, as much as on the disciplines themselves. ${ }^{12}$ The academic development of the field requires that problems be defined in interdisciplinary ways, for one of the greatest risks in emergency management arises from failure to consider the hidden and unexpected implications of decisions and actions. Therefore, the applied development of the field needs practitioners to be trained as coordinators who can interact effectively with workers from many different professions. Even people who have a very specific, narrowly defined task to perform in emergency situations, such as doctors, nurses, and paramedics, will work better if they have a good understanding of the roles of other participants.

It is axiomatic that emergency management needs to be organized at the grass roots level. ${ }^{12}$ Most people who are trapped under collapsed buildings or lying injured in the streets are not saved by the application of national and 
regional resources, they are rescued and cared for using whatever forces and equipment are available in the local area. It follows, therefore, that the success or failure of emergency action depends on the degree of local self-sufficiency in planning and preparedness. However, it also is clear that there needs to be standardization between one emergency preparedness authority and the next in order to guarantee interoperability when an emergency covers an area larger than a single jurisdiction.

To some extent, the money that has flooded into antiterrorism preparedness has helped emergency management to evolve. But, on the other hand, the secrecy with which many counter-terrorism plans are developed has not aided the promotion of standardization and interoperability. Moreover, there has been a tendency to plan at the national and regional levels rather than the local level; yet, even issues of national security will not eclipse the need for local responses to terrorist outrages.

\section{Growth of the Security Industry}

One consequence of the new emphasis on combating terrorism has been the growth of the security industry. This has taken several forms: the development of technology for monitoring and detection of threats; the formation of security corps-which some commentators regard as akin to private armies; and the growth of services for maintaining business continuity. ${ }^{13}$

Emergency planning and management inherently are difficult to privatize, as the vagaries of disaster make profitability uncertain. However, the transfer of many services formerly owned and run by governments to private companies has led to a complex relationship between the public sector and the service providers. New legislation on emergency management in the United Kingdom identifies the private companies that provide fundamental services in transportation, utilities, and communications, and imposes a statutory obligation on them to cooperate with government agencies in the management of emergencies. It also commits the agencies to provide support for the companies in assessing risks and planning for contingencies.

As noted above, one of the most serious challenges in modern emergency management is to ensure that plans are compatible between different agencies and jurisdictions. Lack of compatibility may lead the organizations to work at cross purposes when an emergency occurs. Despite the potential complexities, nevertheless, it is encouraging that private companies increasingly are interested in planning for contingencies and disasters. Studies show that companies that did not anticipate known and credible threats to their operations were much more likely to fail after disaster strikes and ruins their assets or disrupts their business. However, there is a growing discrepancy between planning to meet genuine contingencies and planning to manage the company's reputation. While it is true that through its effect on sales, catastrophic loss of image can lead a company straight to bankruptcy, image management alone cannot solve life-and-death problems of safety, recovery, and continuity of service. ${ }^{14}$

\section{Homeland Security or Civil Contingencies?}

All of these changes are taking place against the background of a particular pattern of evolution of the disaster management field. In the $1950 \mathrm{~s}$, as the Cold War got underway, the United States of America (US) Government funded the National Opinion Research Center with the objective of gauging the possible societal effects of a major attack with weapons of mass destruction. ${ }^{15}$ In the absence of anything of the sort, the researchers used highly destructive, suddenimpact natural events-principally tornadoes, hurricanes, and earthquakes - as analogues. Instead of revealing the dreadful fragility of society, a corpus of sociological findings began to be built up that showed tremendous resilience. Panic was revealed to be a rare and transient phenomenon; ${ }^{16,17}$ the "therapeutic community"18 or "post-disaster eutopia"19 evolved as an outlet for people's charitable instincts; and, far from fleeing the disaster area, people converge upon it in huge numbers. ${ }^{20}$

For its protagonists, the Cold War had three distinct advantages. First, there was a clear enemy; not the impartial vagaries of nature, but a malevolent force that had to be combated or faced down. Second, command and control procedures simplified the process of tackling the threat by sweeping aside the need for transparency and accountability. Third, secrecy obviated the need to indulge in protracted and chaotic exercises in public consultation. It could be used to cover up mistakes and impose arbitrary decisions on people. In fact, the Cold Warriors never went away. Evidently, they were itching to return to the forefront of civilian preparedness activities. ${ }^{21}$

From the 1970 s to the 1990 s, the world of emergency management underwent a slow but steady evolution from civil defense to civil protection. This involved a series of changes. To begin with, there was a gradual movement away from a military command and control ethic to a more collaborative, civilian approach based upon problem-solving methodologies. Emergency plans were adopted more widely and were compiled more rigorously. At the same time, there was increasing recognition that generic plans were needed, rather than those relating to specific hazards, as the range of emergencies that could afflict an area is potentially wide, and it is more efficient to have one adaptable, generic plan than several specific ones. In synthesis, emergency management gradually moved towards becoming a fully-fledged profession: this facilitated the adoption of a more professional attitude to managing emergencies.

Encouraging though these trends are, the period since the 1990s has been one of both positive and negative changes. In the US, the "war on terrorism" has restricted the scope of emergency preparedness, and thus, some would say, has impoverished the field. ${ }^{22}$ Indeed, the "war on terrorism" is not a war in the traditional sense of the term, but takes the form of a protracted series of skirmishes. On the other hand, low-intensity conflict perhaps is more typical of modern warfare than is the clash of armies on the battlefield. Whatever it is, in Europe, by contrast, there has been a subtle change of emphasis from civil protection to civil contingencies management. Thus, we see a 
divergence between the US approach, apparently allembracing, but in practice focused on anti-terrorism issues, and the European approach. The latter has extended civil protection to cover issues of social and medical security, including natural epidemics (e.g., severe acute respiratory syndrome (SARS)) and epizootics (e.g., foot-and-mouth disease), demonstrations and manifestations, blockades and sudden losses of basic services. It is not that the US strategy fails to account for these risks, but there is a distinct difference of emphasis (and investment) between civil contingencies management and homeland security.

\section{The Scenario Problem}

There are several reasons why terrorism is difficult to characterize and predict. To begin with, it stems from deliberate human malevolence rather than the impartiality of nature or the relative impartiality of human error. Secondly, the threat it poses may be designed to be unpredictable. Thirdly, the causal chain may be longer and more complex than that which explains other forms of disaster; and, finally, there are deep contradictions in the motives and motivations of the perpetrators and those who support them. Thus, planning scenarios to counteract future terrorist outrages usually are contentious.

In a Rand Corporation scenario that predates the attacks on New York City and Washington, DC, 23 a light aircraft is used to jettison anthrax spores onto the city of San Francisco. Panic and chaos reign, two million people flee the city, 1.6 million are contaminated and one million die. Hospitals and all emergency services are completely overwhelmed. This may be a feasible scenario, but it is not what actually happened.

When anthrax was used as a terrorist weapon in the United States, there was mass disruption, but, thanks to timely intervention, only a few deaths occurred. The fabric of society remained intact. Of course, the counter-argument is that terrorists had a known interest in both the weapon, anthrax, and the means of delivery, crop-spraying aircraft. Yet, common sense should have highlighted the difficulty of breeding enough anthrax, turning the spores into viable weapons of mass destruction (rather than mere dangerous pathogens), and delivering them without falling sick before that could be achieved. ${ }^{24}$

At the same time, there are credible scenarios that hardly have been given a thorough examination. Consider, for example, the contamination of a major geographical node with a widely dispersed radioactive material, perhaps plutonium, added to a large conventional bomb. At worst, hundreds of square kilometers of land could be put out of commission by the contamination, and so could a major hub upon which many physical communications converge, thus spreading the disruption far and wide.

Not only are the logistics terra incognita, but sociologists are notably absent from much of the debate on terrorist scenarios in modern societies. At the same time, strategists with little appreciation of social realities enthusiastically have been reviving old myths and misconceptions about disaster. In the words of one recently published subtitle, terrorism is bound to "undermine social stability and create mass panic". Well, it might, but there is definitely no sense of inevitability, as sociologists readily would attest. Indeed, this is one of the old disaster "myths" that has survived much debunking. ${ }^{25}$

\section{Conclusion}

These reflections have sought to demonstrate that there are sufficient connections between terrorist outrages and consuetudinary forms of disaster for terrorism to be considered a member of the family of phenomena that includes, for example, hurricanes, earthquakes, industrial accidents, transportation crashes, riots, and epidemics. The problem is that terrorism offers too many potential scenarios, and, according to experience, too many discrepancies between the scenarios that have been worked out and the reality on the ground. Moreover, it encourages a return from civil protection, the modern form of disaster management, to the less evolved forms of civil defense, including a renewed emphasis on command and control. In certain places, notably the United Kingdom, this seems to be promoting a reliance upon excessive secrecy. The casualties of such an approach are democratic rights, transparent decision-making, flexible procedures, and inter-agency collaboration. ${ }^{26}$ Secrecy and command and control go against the grain of the current information and communications technology revolution, which is encouraging openness and tending to flatten the chain of command in emergency management.

At the very least, more open debate is needed on exactly what measures are appropriate responses to the terrorism threat. This requires a more critical approach to the construction and use of planning scenarios. It also requires input from a greater range of professionals working in the constituent disciplines that make up the disaster studies and management field. By elucidating some of the more important issues and procedures, this volume will make an important contribution to the debate.

\section{References}

1. Quarantelli EL (ed): What is a Disaster? Perspectives on the Question. London: Routledge, 1998.

2. Perry RW, Quarantelli EL (eds): What is a Disaster? More Perspectives. International Research Committee on Disasters Book Series, Philadelphia: Exlibris, 2004.

3. Alexander DE: Natural disasters: A framework for research and teaching. Disasters 1991;115(3):209-226.

4. Wijkman A, Timberlake L: Natural Disasters: Acts of God or Acts of Man? Washington, DC: Earthscan, International Institute for Environment and Development, 1984.

5. US NRC: Making the Nation Safer: The Role of Science and Technology in Countering Terrorism. Washington, DC: National Research Council, National Academies Press, 2002.

6. Wisner B: Risk and the neoliberal state: Why post-Mitch lessons didn't reduce EI Salvador's earthquake losses. Disasters 2001;25(3):251-268.

7. Pelling $\mathrm{M}$ (ed): Natural Disasters and Development in a Globalizing World. London: Routledge, 2003.

8. Adams J: Risk: The Policy Implications of Risk Compensations and Plural Rationalities. London: UCL Press, 1995. 
9. Pearson GS: Chemical/biological terrorism: How serious a risk? Politics and the Life Sciences 1996:210-212.

10. Horlick-Jones T: Modern disasters as outrage and betrayal. International Journal of Mass Emergencies and Disasters 1995;13(3):305-315.

11. Lupton D: Risk: Key Ideas. London: Routledge, 1999.

12. Alexander DE: Principles of Emergency Planning and Management. Harpenden, UK: Terra Publishing, New York: Oxford University Press, 2002.

13. Buzan B, Waever O, de Wilde J: Security: A New Framework for Analysis. New York: Lynn Rienner, 1997.

14. Dalton D: Rethinking Corporate Security in the Post-9/11 Era. London: Butterworth-Heinemann, 2003.

15. Fritz CE, Marks ES: The NORC studies of human behavior in disaster. Journal of Social Issues 1954;10(3):26-41.

16. Quarantelli EL: The nature and conditions of panic. American Journal of Sociology 1954;60(3):267-275.

17. Johnson NR: Panic and the breakdown of social order: Popular myth, social theory, empirical evidence. Sociological Focus 1987;20(3):171-183.

18. Gist R, Lubin B (eds): Psychosocial Aspects of Disaster. New York: Wiley, 1989.

19. Wolfenstein M: Disaster: A Psychological Essay. Glencoe, Illinois: Free Press, 1957.
20. Fritz CE, Mathewson JH: Convergence Bebaviour in Disasters. Disaster Study no. 9. Washington, DC: National Research Council, National Academy Press, 1957.

21. Alexander D: From civil defence to civil protection-and back again. Disaster Prevention and Management 2002;11(3):209-213.

22. Mitchell JK: The fox and the hedgehog: Myopia about homeland security in U.S. policies on terrorism. Research in Social Problems and Public Policy 2003;11:53-72.

23. Chalk P: The agroterrorism threat. In RAND Bioterrorism Conference, Section I: Threat Panel: The Threat Beyond 2000; Santa Monica CA, 08 February 2000. Available at http://www.rand.org/nsrd/bioterr/chalk.htm. Accessed 13 September 2001.

24. Bartlett JG: Applying lessons learned from anthrax case history to other scenarios. Emerging Infectious Diseases 1999, 5(4). Available at http://www.cdc.gov/ncidod/eid/vol5no4/bartlett.htm. Accessed on 13 September 2001.

25. Noji EK: The Nature of Disaster. In Noji, EK (ed) The Public Health Consequences of Disasters. Oxford, UK: Oxford University Press, 1997, pp 17-18.

26. Alexander DE: Democracy, warfare and disaster management. RUSI Security Monitor 2003;2(5):15-17. 